\title{
Survival probability in self immolation attempters: a prospective observational cohort study
}

\author{
Mehdi Moradinazar, Ph.D., ${ }^{1}$ Saeed Amini, Ph.D., ${ }^{2}$ Mohammadreza Baneshi, Ph.D., ${ }^{2}$ \\ Farid Najafi, M.D., ${ }^{1}$ Nikzad Abbasi, Ph.D., ${ }^{3}$ Mari Ataee, M.D. ${ }^{4}$
}

\begin{abstract}
${ }^{1}$ Research Center for Environmental Determinants of Health (RCEDH), Kermanshah University of Medical Sciences, Kermanshah, Iran ${ }^{2}$ Research Center for Modeling in Health, Institute for Futures Studies in Health, Kerman University of Medical Sciences, Kerman, Iran ${ }^{3}$ Department of Political Sciences, Tarbiat Modares University, Tehran, Iran

${ }^{4}$ Students Research Committee, Kermanshah University of Medical Sciences, Kermanshah, Iran
\end{abstract}

ABSTRACT

BACKGROUND: Self-immolation is one of the most violent methods of suicide in developing countries. The objective of the present study was to investigate the survival rate and factors affecting survival of self-immolation patients.

METHODS: All people either died or hospitalized for intentional burns were assessed in Kermanshah province between 2010 and 2013. Required information was gathered from two sources, Kermanshah province legal medicine and burn center of Imam Khomeini Hospital. Survival function was assessed through Cox regression. The data were analyzed with Stata 12 software.

RESULTS: Between 2010 and 2013 (three years), 446 people attempted self-immolation, of which 370 were females (83\%). In general, 276 people $(61.8 \%)$ died due to severity of the burns. The median of survival time was $47 \pm 5$ days. The survival rate after one day, one week, and 21 days after accident was $86 \%, 52 \%$, and $38 \%$, respectively. Multivariate analysis demonstrated that burn was the most powerful risk factor, sothe risk in those with over $70 \%$ burns is 17 times more than those with burns less than $30 \%$.

CONCLUSION: Burn percentage is the strongest risk factor, those with high burns percentage should be hospitalized quickly and without waste of time.

Key words: burns percentage; self-immolation; survival rate.

\section{INTRODUCTION}

It cannot be found in any period of history in which any case of suicide has not been registered. Based on the World Health Organization (WHO) report, during the past 45 years, the rate of suicide attempts has increased $60 \%$ in the world, and this growing trend is expected to be continued. [1,2] The method of suicide is different in various countries. ${ }^{[3,4]}$ The most violent method of suicide is self-immolation, ${ }^{[5]}$ which is more prevalent in developing countries ${ }^{[6,7]}$ although the prevalence of suicide is high in developed countries, but

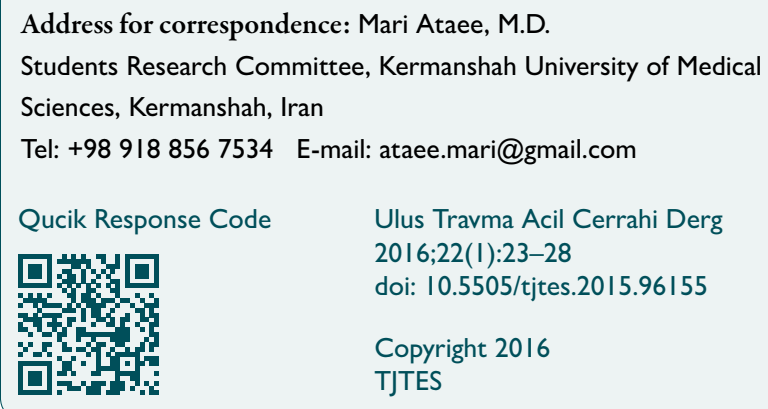

this method accounts for a small percentage (0.6 to $1 \%$ ) of all suicides. ${ }^{[4,8]}$ In Iran, 34\% of suicide-related deaths are due to self-immolation. ${ }^{[6,8,9]}$ Indeed, self-immolation after disasters and breast cancers is the third factor for Potential Years of Life Lost (YPLL) in Iranian women. ${ }^{[10]}$

Suicide is a complicated phenomenon which can be affected by various factors. ${ }^{[1,12]}$ Suicide attempts in women are higher than in men, but deaths due to suicide in men are higher than in women. ${ }^{[13]}$ The role of these factors in survival rate is not clear in people who have attempted suicide. Between all methods of suicide, self-immolation is more deleterious, painful, costly, and fatal, ${ }^{[14,15]}$ and people who burn themselves are hardly treated. ${ }^{[12,16]}$ This study is designed to assess the survival rate and affecting factors of survival in self-immolation attempters in one of the west provinces of Iran (Kermanshah) which has one of the highest rates of suicide and self-immolation. ${ }^{[10]}$

\section{MATERIALS AND METHODS}

\section{Study population}

All people died or hospitalized due to self-immolation were 
assessed between 2010 and 2011 ( 24 months). Data were collected with a defined intersectional coordination, from Kermanshah legal medicine organization and also the burn center of Imam Khomeini Hospital, which is the main burn center of the province in seventh medical hub of the country. Imam Khomeini Hospital is the only medical center for burns patients in the Kermanshah province and is a referral center for Kurdistan, Ilam, and Lorestan provinces, which offer burnrelated medical services to a population of nearly 6 million people.

Required information was obtained in two ways: interview with friends, relatives, and other people who had relationship with the patient and from medical documents. Assessed variables included age, sex, job, ignition factor, drug dependence based on WHO definition, ${ }^{[17]}$ history or existence of physical illness, and eventually Total Body Surface Area (TBSA) based on Lund and Browder's chart. ${ }^{[18]}$ All of the hospitalized patients were followed up till death and/or recovery and discharge.

\section{Data Analysis}

In order to determine affecting factors in self-immolation attempters, Schoenfeld residuals graph was used to assess proportional hazard. In univariate assessing, Kaplan Maier method was used and compared by Log Rank test. Cox regression was used for comparing survival rate in multivariate study. In this study, variables with $\mathrm{p}<0.3$ were introduced to multivariate survival model and non-meaningful variables were excluded from the final model by using forward method. In addition to the tests used in survival analysis, paired $\mathrm{T}$ was used for comparing means in groups and chi-square test was used for comparing proportions. It is worth noting that all analysis was conducted in Stata 12 software and a $p<0.05$ was considered as meaningful.

\section{Ethical Considerations}

A psychologist team from Imam Khomeini Hospital interviewed with self-immolation attempters or their families. Present study was permitted by the Ethics Committee of Kermanshah University of Medical Science. Furthermore, ethical issues were considered in this study based on the Helsinki Declaration.

\section{RESULTS}

During 2010 to 2013 , four hundred and forty-six people attempted self-immolation, of whom $83 \%(n=370)$ were females. Two hundred and seventy-six people of all attempters $(61.8 \%)$ died due to the severity of self-immolation, of whom two hundred and twenty-eight (82.6\%) were females. The observed difference between fatality and sex was not meaningful $(p=0.82)$.

The lowest survival rate in self-immolation attempters, who died due to the severity of injury, was one day and the highest survival rate was eighty-six days. The median of survival time was $47 \pm 5$ days (Fig. I).

22.4 percent $(n=62)$ of those who attempted suicide, died of severe burns on the first day, and $72.8 \%(n=201)$ of the deceased people, died in the first week after self-immolation. One day, one week and 21 day survival rate after accident in self-immolation attempters were $86 \%, 52 \%$ and $38 \%$, respectively. Mean age of self-immolation was $30 \pm 0.6,29 \pm 1.2$ in men and $30 \pm 0.7$ in women. This difference in age was not meaningful $(p=.089)$. As demonstrated in Figure 2, the ratio of fatal suicides was constant until the age of 45 , but increased after the age of 45 (Fig. 2).

Mean Total Body Surface Area (TBSA) in self-immolation attempters was $63 \% \pm \mathrm{I}$. That is, TBSA in 96 people $(21.5 \%)$ was more than $90 \%$. The mean burns percentage for men was $70 \pm 3$ and for women was $61 \pm 1$, and this difference in mean burns percentage in two genders was not meaningful $(p<0.009)$.

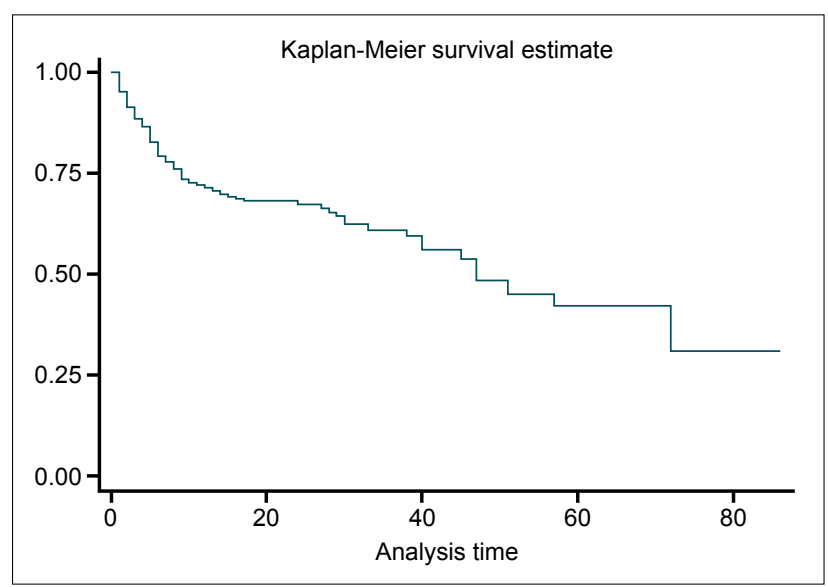

Figure 1. Overall survival curve of self-immolation.

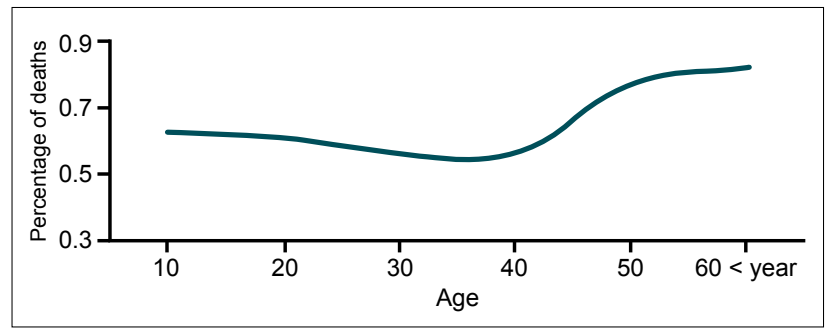

Figure 2. Percentage of deaths based on age pations.

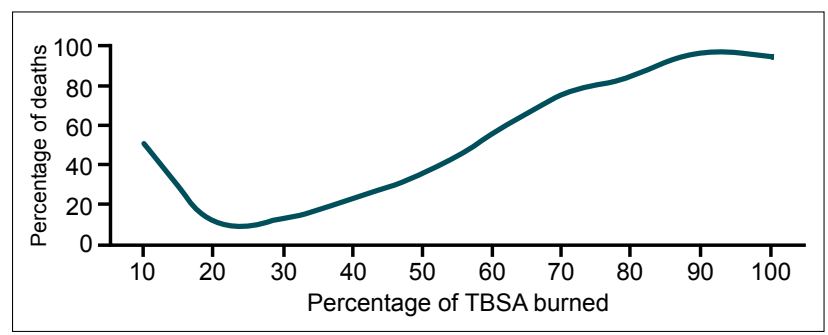

Figure 3. Percentage of deaths based on percent of the total body surface area (TBSA). 
Table I. Characteristics of self-immolation attempters base on of univariate and multivariate survival analysis

\begin{tabular}{|c|c|c|c|}
\hline Variable & Mortality/frequency (\%) & Crude HR $(95 \%$ CI) & Adjusted HR $(95 \% \mathrm{Cl})$ \\
\hline \multicolumn{4}{|l|}{ Sex } \\
\hline Male & $48 / 76(63.1)$ & I & - \\
\hline Female & $228 / 370(61.6)$ & I $(0.6-\mid .6)$ & - \\
\hline \multicolumn{4}{|l|}{ Age } \\
\hline lower 30 year & I78/289 (6I.8) & 1 & I \\
\hline $31-50$ year & $63 / 114(55.2)$ & I (0.7-I.7) & I (0.7-I.6) \\
\hline Uper 51 year & $34 / 43(79.0)$ & $3.7(1.6-8.9)$ & $3.5(1.3-9.7)$ \\
\hline \multicolumn{4}{|l|}{ Education } \\
\hline Illiterate & $62 / 101$ (6I.3) & I & - \\
\hline Less than diploma & $137 / 223(6 \mid .4)$ & $0.85(0.5-1.3)$ & - \\
\hline Diploma and upper & $77 / 122(63.1)$ & $0.79(0.4-1.3)$ & - \\
\hline \multicolumn{4}{|l|}{ Marital status } \\
\hline Single & $161 / 256(62.8)$ & 1 & 1 \\
\hline Married & $98 / 161$ (60.8) & $0.9(0.7-1.2)$ & $1.9(1.07-3.7)$ \\
\hline Widow & $8 / 29(27.5)$ & $1.2(0.7-2.1)$ & $2.2(0.8-6.0)$ \\
\hline \multicolumn{4}{|l|}{ Method } \\
\hline Kerosene & $231 / 362(63.8)$ & 1 & - \\
\hline Gasoline & $12 / 26(46.1)$ & $0.8(0.4-1.5)$ & - \\
\hline Gas & $20 / 28(71.4)$ & $1.5(0.9-2.4)$ & - \\
\hline Other & I3/30 (43.3) & $0.8(0.4-1.4)$ & - \\
\hline \multicolumn{4}{|l|}{ Drug dependence } \\
\hline No & $232 / 380(61.0)$ & 1 & - \\
\hline Yes & $43 / 65(66.1)$ & I.2(0.9-I.7) & - \\
\hline \multicolumn{4}{|l|}{ Physical disease } \\
\hline No & $204 / 320(63.7)$ & I & - \\
\hline Yes & $68 / 122(55.7)$ & $0.7(0.5-0.9)$ & - \\
\hline \multicolumn{4}{|l|}{ Job } \\
\hline House keeper & $164 / 262(62.8)$ & 1 & 1 \\
\hline Unemployed & $61 / 98(62.2)$ & I.I (0.7-I.4) & $2.1(1.1-4.0)$ \\
\hline Employee & $51 / 86(59.3)$ & $0.9(0.7-1.3)$ & $0.9(0.4-1.7)$ \\
\hline \multicolumn{4}{|l|}{ Socioeconomic } \\
\hline Poor & $134 / 219(61.1)$ & 1 & - \\
\hline Moderate & $187 / 187(100)$ & $0.9(0.7-1.2)$ & - \\
\hline Good & $20 / 20(100)$ & $0.7(0.3-1.3)$ & - \\
\hline \multicolumn{4}{|l|}{ TBSA } \\
\hline lower $30 \%$ & $10 / 69(14.4)$ & 1 & I \\
\hline $30-70 \%$ & $85 / 183(46.4)$ & $3.08(1.6-5.9)$ & $4(1.7-6.5)$ \\
\hline Upper $70 \%$ & $181 / 194(93.3)$ & I6.8 (8.8-32) & $17.4(10-34)$ \\
\hline \multicolumn{4}{|l|}{ Place } \\
\hline City & $122 / 208(58.9)$ & I & - \\
\hline Village & $153 / 237(64.5)$ & I. 17 (0.9-I.4) & - \\
\hline \multicolumn{4}{|l|}{ History of suicide attempt } \\
\hline No & $35 / 67(52.2)$ & I & I \\
\hline First and second time & $194 / 30 \mid(64.4)$ & $\mathrm{I} .02(0.7-1.4)$ & $0.47(0.2-0.74)$ \\
\hline More than 2 & $47 / 78(60.2)$ & $0.8(0.5-1.3)$ & $0.34(0.2-0.6)$ \\
\hline
\end{tabular}


As demonstrated in Figure 3, there is a direct relationship between Total Body Surface Area (TBSA) and mortality rate, and hence mortality rate increases with increase of TBSA $(r=0.64, p<0.001)$.

In the univariate study of survival rate in self-immolation attempters, age, physical illness, and Total Body Surface Area (TBSA) were meaningful amongst various variables demonstrated in Table I.

In order to exclude confounder variables and considering probable errors in estimations, those variables with $p<0.3$ were introduced to the multivariate study. Given that, proportional hazard assumption was confirmed for all assessed variables, multivariate analysis was analyzed by Cox regression method and forward method and Likelihood ratio test were used to determine multivariate model.

As demonstrated by multivariate analysis, burns percentage is the strongest risk factor. The risk of those with burns percentage higher than $70 \%$ was 17 times more than those with burns percentage lower than $30 \%$. In general, each unit increase in burns percentage causes $6 \%$ increase in mortality risk of self-immolation.

Other findings of this study demonstrate that whatever the number of suicide increases, mortality risk of self-immolation reduces. In the present study, those with 2 times history of suicide attempt had $53 \%$ more survival rate in comparison to those with no suicide history, and this rate for those with more than 2 time history of suicide was $66 \%$ in comparison with those with no history of suicide.

Among other variables which were meaningful in the multivariate analysis but were not meaningful in the univariate study, we can state high mortality rate in married people than single people, and unemployed people than housekeepers (Table I).

27 percent $(n=122)$ of self-immolation attempters had a history of physical illness. As demonstrated in Table I, history of physical illness was meaningful in the multivariate analysis. The mean of burns percentage in healthy people was $55 \pm 2$, and for those with history of physical illness, it was $65 \pm 1.5$. This difference was meaningful $(p<0.001)$.

\section{DISCUSSION}

This study is among the first studies to examine the survival rate and affecting factors of survival in self-immolation attempters, therefore, it is not possible to compare affecting factors of survival in self-immolation with other studies. The findings of this study demonstrated that the highest mortality rate of self-immolation was in the first 24 hours after accident. Similar results have been obtained in similar studies, ${ }^{[12,19]}$ and it is believed that the most important cause of mortality of self-immolation in the first 24 hours is loss of fluids and electrolytes. Therefore, the first step for the survival of a patient should be compensating lost fluids and electrolytes, especially compensating half of the lost fluids during the first 8 hours after self-immolation. ${ }^{[20]}$

The strongest risk factor affecting survival of self-immolation attempters was Total Body Surface Area (TBSA). After multivariate adaptation, for each unit increase in burns percentage, death risk ratio (HR) in self-immolation attempters increased I.2 times. In studies conducted on nine hundred and fifty-two unintentional burns above $30 \%$ in the USA, the survival rate and mortality ratio of burns had the highest relation with Total Body Surface Area (TBSA). ${ }^{[2 I]}$

As demonstrated in Figure 3, mortality ratio of self-immolation in those with burns percentage less than $20 \%$ was higher than those with burns percentage between 20 to $40 \%$. One of the reasons can be due to poor reporting. In Iran and most other countries, people try to report self-immolation as an unintentional accident, due to political, cultural, and social problems they probably face after suicide. Although this poor reporting varies from one country to another, it is more when side effects of the suicide is mild and is not resulted in death. In this study, most of those with mild burns tried to report their self-immolation as unintentional burns. Since Imam Khomeini Hospital of Kermanshah is a referral center in the west of Iran, the second reason can be due to transfer of severe burns cases which are probably in vital organs. It should be noted that the number of these patients from other medical centers was less than I\% of all attempters.

In the univariate analysis, those with previous history of physical illness had higher survival rate than healthy people. Given that physical illness was not meaningful in the multivariate analysis, a positive relationship between burns percentage and history of physical illness is found. 30 percent increase in survival rate in those with physical illness can be due to mild burns in them.

In the univariate analysis, previous history of suicide was not meaningful, but in the multivariate analysis, the survival rate of those with previous history of suicide was higher than those with no previous history. These can be due to uncontrolled confounding variables which are not meaningful in univariate studies.

Other results of this study demonstrate that the ratio of fatal self-immolations up to the age of 45 is constant. However, after the age of 45 , the ratio of fatal suicides increases. It is believed that, with aging, the human skin undergoes main substantial changes such as perforation of dermal vessels, decreased subcutaneous fat, and atrophy of skin-dependent structures, which meansthat the ability of the immune system to fight against secondary infections will be reduced. When self-immolation or burns occurs in aged people, it is deeper 
and more severe, and as a result, the recovery rate and duration of survival in aged people are less than other groups. ${ }^{[22,23]}$

In this study, more than $80 \%$ of self-immolations occurred in women, and similar results were achieved from most of other studies in developing countries such as Uzbekistan, ${ }^{[24]}$ Afghanistan, ${ }^{[25]}$ India, ${ }^{[26]}$ and Sri Lanka; ${ }^{[1]]}$ however these results were different from other studies that were conducted in most of the developed countries such as Germany, ${ }^{[27]}$ Australia, ${ }^{[28]}$ Finland, ${ }^{[29]}$ England and Wales ${ }^{[30]}$ wheremost of the self-immolations were in men.

More than $60 \%$ of self-immolations have resulted in death. In II studies conducted on self-immolation in Iran, the lowest mortality rate is $56 \%$ and the highest mortality rate is $76 \%{ }^{\left[{ }^{12]}\right]}$ In studies conducted on self-immolation in the USA, Australia, the Netherlands, Egypt, and Spain, 36\%, 47\%, 21\%, $49 \%$, and $30 \%$ have resulted in death, respectively. ${ }^{[29]}$ Various reasons can be mentioned for differences in mortality rate of self-immolation between Iran and other countries. One of these reasons was burns percentage. The burns percentage in this study was over $60 \%$, which was higher than other mentioned studies (mean burns percentage of mentioned studies is $42 \%$ ). Another reason can be difference in quality and quantity of medical services.

About $80 \%$ of self-immolations occurred with petroleum (Table I). In similar studies, mostself-immolation cases were carried out by petroleum. ${ }^{[7,19]}$ Our study researchers expected a positive relationship between the caustic agent and survival rate, but as demonstrated in Table I, there was no meaningful relation between caustic agent and survival rate of self-immolation attempters in the univariate and multivariate analysis.

There was no meaningful difference in survival rate function of both genders, but like other similar studies, the burns percentage of self-immolation attempters in men was higher than in women. ${ }^{[3]}$

It can be elicited from the results of this study that the mortality rate of self-immolation is very high and the median of survival is very low. Since burns percentage is the strongest risk factor, those with high burns percentage should be hospitalized quickly and without waste of time. Although we were able to investigate various factors affecting the survival rate of self-immolation attempters, a study with more samples considering indices such as region of burns and impact on airways should be conducted.

\section{Acknowledgement}

The authors gratefully acknowledge the Research Center for Environmental Determinants of Health (RCEDH), Kermanshah University of Medical Sciences, for the financial support.

Conflict of interest: None declared.

\section{REFERENCES}

1. Schmidtke A, Weinacker B, Apter A, Batt A, Berman A, Bille-Brahe U, et al. Suicide rates in the world: update. Archives of Suicide Research 1999;5:81-9.

2. Platt S, Bille-Brahe U, Kerkhof A, Schmidtke A, Bjerke T, Crepet P, et al. Parasuicide in Europe: the WHO/EURO multicentre study on parasuicide. I. Introduction and preliminary analysis for 1989. Acta Psychiatr Scand 1992;85:97-104.

3. Boor M. Methods of suicide and implications for suicide prevention. J Clin Psychol 1981;37:70-5.

4. Ajdacic-Gross V, Weiss MG, Ring M, Hepp U, Bopp M, Gutzwiller F, et al. Methods of suicide: international suicide patterns derived from the WHO mortality database. Bull World Health Organ 2008;86:726-32.

5. Zarghami M, Khalilian A. Deliberate self-burning in Mazandaran, Iran. Burns 2002;28:115-9.

6. Ahmadi A. Suicide by self-immolation: comprehensive overview, experiences and suggestions. J Burn Care Res 2007;28:30-41.

7. Dastgiri S, Kalankesh L, Pourafkary N. Epidemiology of self-immolation in the North-West of Iran 2005.

8. Ahmadi A, Ytterstad B. Prevention of self-immolation by communitybased intervention. Burns 2007;33:1032-40.

9. Mabrouk AR, Mahmod Omar AN, Massoud K, Magdy Sherif M, El Sayed N. Suicide by burns: a tragic end. Burns 1999;25:337-9.

10. Hatami H, Razavi M, Eftekhar H, Majlesi F, Sayed Nozadi M, Parizadeh S. Textbook of public health. Tehran: Arjmand 2004.

11. Laloë V, Ganesan M. Self-immolation a common suicidal behaviour in eastern Sri Lanka. Burns 2002;28:475-80.

12. Mehrpour O, Javadinia SA, Malic C, Dastgiri S, Ahmadi A. A survey of characteristics of self-immolation in the east of Iran. Acta Med Iran 2012;50:328-34.

13. Andreasen NC, Noyes R Jr. Suicide attempted by self-immolation. Am J Psychiatry 1975;132:554-6.

14. Ahmadi A, Mohammadi R, Stavrinos D, Almasi A, Schwebel DC. Selfimmolation in Iran. J Burn Care Res 2008;29:451-60.

15. Westermarck E. Suicide: A Chapter In Comparative Ethics* ${ }^{*}$ The Sociological Review 2011;1:12-33.

16. Pegg S, Gregory J, Hogan PG, Mottarelly IW, Walker LF. Epidemiological pattern of adult burn injuries. Burns 1979;5:326-34.

17. Merikangas KR, McClair VL. Epidemiology of substance use disorders. Hum Genet 2012;131:779-89.

18. Richard A, Gardner RA. Should courts order PAS children to visit/reside with the alienated parent? A follow-up study. American Journal of Forensic Psychology 2001;19:61-106.

19. Dastgiri S, Kalankesh LR, Pourafkary N, Vahidi RG, Mahmoodzadeh F. Incidence, survival pattern and prognosis of self-immolation: a case study in Iran. Journal of Public Health 2006;14:2-6.

20. Wolfe RR. Review: acute versus chronic response to burn injury. Circ Shock 1981;8:105-15.

21. Kraft R, Herndon DN, Al-Mousawi AM, Williams FN, Finnerty CC, Jeschke MG. Burn size and survival probability in paediatric patients in modern burn care: a prospective observational cohort study. Lancet 2012;379:1013-21.

22. Smith DL, Cairns BA, Ramadan F, Dalston JS, Fakhry SM, Rutledge R, et al. Effect of inhalation injury, burn size, and age on mortality: a study of 1447 consecutive burn patients. J Trauma 1994;37:655-9.

23. Conil JM, Georges B, Lavit M, Seguin T, Tack I, Samii K, et al. Pharmacokinetics of ceftazidime and cefepime in burn patients: the importance of age and creatinine clearance. Int J Clin Pharmacol Ther 2007;45:52938.

24. Alimova D, Azimova N. Women's position in Uzbekistan before and after independence. Gender and identity construction: Women of Central 
Asia, the Caucasus and Turkey 2000;68:293-306.

25. Gall C. For more Afghan women, immolation is escape. The New York Times 2004.

26. Jaiswal AK, Aggarwal H, Solanki P, Lubana PS, Mathur RK, Odiya S. Epidemiological and socio-cultural study of burn patients in MY Hospital, Indore, India. Indian Journal of Plastic Surgery 2007;40:158-63.

27. Rothschild MA, Raatschen HJ, Schneider V. Suicide by self-immolation in Berlin from 1990 to 2000. Forensic Sci Int 2001;124:163-6.

28. Cameron DR, Pegg SP, Muller M. Self-inflicted burns. Burns
1997;23:519-21.

29. Palmu R, Isometsä E, Suominen K, Vuola J, Leppävuori A, Lönnqvist J. Self-inflicted burns: an eight year retrospective study in Finland. Burns 2004;30:443-7.

30. Prosser D. Suicides by burning in England and Wales. Br J Psychiatry 1996;168:175-82.

31. Mehrpour O, Javadinia SA, Malic C, Dastgiri S, Ahmadi A. A survey of characteristics of self-immolation in the east of Iran. Acta Med Iran 2012;50:328-34.

\title{
ORİJINAL ÇALIŞMA - ÖZET
}

\section{Kendini yakarak intihara teşebbüs eden kişilerde sağ kalma olasılığı:}

İleriye yönelik, gözlemsel bir kohort çalışma

\section{Dr. Mehdi Moradinazar, ${ }^{1}$ Dr. Saeed Amini, ${ }^{1}$ Dr. Mohammadreza Baneshi, ${ }^{1}$ Dr. Farid Najafi, ${ }^{2}$} Dr. Nikzad Abbasi, ${ }^{3}$ Dr. Mari Ataee ${ }^{4}$

\author{
'Sağlıkta Çevresel Etmenler Araştırma Merkezi, Kermanşah Tıp Bilimleri Üniversitesi, Kermanşah, İran \\ 2Sağlıkta Modelleme Araştırma Merkezi, Sağlıkta Gelecek Çalışmalar Enstitüsü, Kermanşah Tıp Bilimleri Üniversitesi, Kerman, İran \\ ${ }^{3}$ Tarbiat Modares Üniversitesi, Siyasi Bilimler Bölümü, Tahran, İran \\ ${ }^{4}$ Öğrenci Araştırma Komitesi, Kermanşah Tıp Bilimleri Üniversitesi, Kermanşah, İran
}

AMAÇ: Kendini yakma, gelişmekte olan ülkelerde gözlenen en vahşi intihar yöntemidir. Bu çalışmanın amacı, kendini yakarak intihara teşebbüs eden hastalarda sağ kalım oranlarını ve sağ kalıma etki eden faktörleri araştırmaktı.

GEREÇ VE YÖNTEM: 20I0-20I3 yılları arasında Kermanshah ilinde kasti yanıklar sonucunda hastaneye kaldırılan veya ölen bütün kişiler değerlendirildi. Gerekli tüm bilgiler Kermanshah ili Adli Tıp Kurumu'ndan ve İmam Humeyni Hastanesi Yanık Ünitesi'nden alındı. Cox regresyonu yoluyla sağ kalım fonksiyonu değerlendirildi. Veriler, Stata 12 yazılımı ile analiz edildi.

BULGULAR: 20I0-20I3 yılları arasında (üç yıl), kendini yakarak intihara teşebbüs eden 446 kişinin 370'i kadındı (\%83). Genel olarak, 276 kişi (\%6।.8) yanıklarının ciddiyeti dolayısıyla öldü. Ortalama sağ kalım süresi $47 \pm 5$ gündü. Kaza sonrası birinci gün, birinci hafta ve 21 . gün sağ kalım oranları sırasıyla \% $86, \% 52$ ve \%38 idi. Çok değişkenli analiz en güçlü risk faktörünün yanıklar olduğunu gösterdiği için \%70'den fazla yanığı olan kişilerdeki risk faktörü \%30'dan az yanığı olan kişilerdekinden 17 kat daha fazla olduğu ortaya konmuştur.

TARTIŞMA: Yanık yüzdesi en güçlü risk faktörü olmakla birlikte yüksek yanık yüzdesine sahip olan kişilerin hızlıca ve vakit kaybetmeden hastaneye kaldırılmaları gerekmektedir.

Anahtar sözcükler: Kendini yakma; sağ kalım oranı; yanık yüzdesi.

Ulus Travma Acil Cerrahi Derg 20I6;22(I):23-28 doi: 10.5505/tjtes.2015.96।55 